\title{
Competing for Talent: Diffusion of an Innovation in New Zealand's Immigration Policy
}

Richard Bedford

Professor of Migration Research

Auckland University of Technology

Private Bag 92006

Auckland 1142

New Zealand

Corresponding Author

Paul Spoonley

p.spoonley@massey.ac.nz

+6494418170
Paul Spoonley

Distinguished Professor/Pro Vice-Chancellor

College of Humanities and Social Sciences

Massey University

Private Bag 102904

Auckland 0745

New Zealand

\section{Abstract}

In 2003, New Zealand introduced a novel "expression of interest” (EOI) system for selecting skilled migrants. In 2012, Australia adopted a similar approach while the Canadian government is proposing to adopt a variant of the EOI system in 2015. From being a follower of Canadian and Australian immigration policy initiatives, New Zealand has become the innovator. This paper examines the reasons for this significant policy shift and reviews some outcomes of the EOI system during the first decade of operation. As the international competition for talent intensifies, such policy innovation is essential if countries are going to attract skilled migrants.

\section{Keywords}

Immigration policy, skilled migrant selection, EOI systems, outcomes for skilled migrants

A defining feature of the intensified global competition for talent is the close monitoring of immigration policy initiatives in countries with similar histories of international migration (Papademetrious and Sumpton, 2013). Canada, Australia and New Zealand are internationally known for their pro-active points selection systems that favour migrants with particular mixes of skills, capital and offers of employment. When one country changes immigration policy, either to improve the operation of its selection system, or to ensure better employment outcomes for migrants approved for permanent entry, the other two countries monitor the new initiatives closely. Usually it is Australia or Canada that are the innovators. But in the case of what is being referred to as the "Expression of Interest" (EOI) model in 
Canada $^{1}$, a two-stage selection system that allows for active selection of prospective immigrants with skills in demand in the labour market, and which effectively replaces inventories (backlogs) of applications for residence with short-term pools of prospective migrants, it was New Zealand that was the innovator.

The Government of Canada is scheduled to introduce an EOI stage to the selection system used for some of its economic immigration streams in January 2015, following the amendment of its immigration legislation. This is one of a significant number of recent changes in Canada's immigration policy (Alboim and Cohl, 2012), and it draws on the experiences that New Zealand and Australia have had with the EOI model. In recent years, applications for residence in all three countries have greatly exceeded both the processing capacities of agencies responsible for deciding who can be admitted in the skilled migrant streams and the supply of job offers for migrants. Delays in processing applications have created considerable frustration for both migrants and the immigration authorities, especially in Canada where there has been provision in the legislation for all applications for residence to be considered irrespective of the length of the queue (inventory) (Hiebert, 2006).

A relatively simple innovation in immigration policy in New Zealand in 2003 has improved both the initial selection process for immigrants as well as their labour market outcomes. In the late 2000s, proof of the latter was demonstrated in a comparative study by Hawthorne (2011) of labour market outcomes for skilled migrants interviewed in New Zealand's and Australia's longitudinal immigration surveys. These findings, coupled with increasing

\footnotetext{
${ }^{1}$ The Senate Standing Committee on Foreign Affairs and International Trade, Evidence, 20 November 2013, statement by Maia Welbourne, Senior Director, Strategic Policy and Planning, Citizenship Immigration Canada. http://www.parl.gc.ca/content/sen/committee/412/AEFA/51031E.htm (accessed 23 January 2014).
} 
evidence on the critical role that migrant selection plays in labour market outcomes (CobbClark, 2000; Hawthorne, 2008a; Jasso and Rosenzweig, 2009; Cully, 2011), contributed to a decision by the Australian government to introduce an EOI stage in the selection process for the supply-driven component of their skilled migration program from July 2012. In an environment where there is extensive consultation on immigration issues between officials (and academics) in Australia, Canada and New Zealand ${ }^{2}$, it was inevitable that Canada would explore the utility of this approach as well, especially as it has the effect of eliminating major backlogs of residence applications by migrants. Canada has had such an inventory for many years and this has become a major impediment to the efficient and timely selection of migrants with skills in demand in the labour market (Alboim and Cohl, 2012).

The country that has been the most innovative in skilled migrant selection policy since the mid-1990s is Australia (Hawthorne, 2005, 2007; Cully, 2011). Many of the innovations there have influenced immigration policy development in New Zealand where it is relatively easy to make changes to policy frameworks and settings without having to go through a process of legislative review and amendment (Bedford, 2004; Bedford et al., 2005; Spoonley and Bedford, 2012). In this way, New Zealand's immigration policy and that which applies in Australia have remained quite similar, despite major differences in governance systems (Bedford, 2006). New Zealand's unitary state and single national immigration policy has some advantages when it comes to adopting innovations from other jurisdictions. The absence of a two-tiered system of governance that is common in federal systems, and the associated array of immigration policies that can apply at federal and state/provincial levels, is also conductive to policy innovation and experimentation in New Zealand.

\footnotetext{
2 See, for example, the collaborative research Hawthorne has been doing with academic and policy colleagues in Canada and New Zealand (Birrell et al. 2006; Hawthorne, 2007, 2008, 2011).
} 
The EOI model is arguably New Zealand's most successful policy innovation in the competition for talent since a points-based selection system was introduced in 1991 (Spoonley and Bedford, 2012). It was a logical development, in hindsight, in an immigration policy environment that emphasized efficiency and transparency in selection processes and which prioritised the rapid integration of migrants into the labour market in jobs that made use of their skills. The diffusion of a new approach to selecting 'talent' across three countries that all operate points selection systems is an example of how quickly successful innovations in immigration policy are adopted by competitors. There has not been much published about this particular policy innovation but it is clear that it is having a significant impact on the ‘supply' driven components of skilled migration programs in three countries which are competing for talent.

This paper examines the reasons for this significant policy shift in New Zealand and considers the outcomes of the EOI system during the first decade of operation. The implementation of a twostage approach to migrant selection in New Zealand between December 2003 and December 2005 is reviewed next. This is followed by an assessment of the impact of a significant policy change late in 2005 to introduce two-tiers into the selection process on those selections made between January 2006 and December 2008 when the onset of the Global Financial Crisis (GFC) began to impact on numbers of migrants selected for residence. The third section traces the operation of the selection system between July 2009 and December 2013, spanning the period when two severe earthquakes devastated New Zealand's second largest city, Christchurch. The final substantive section summarises evidence on labour market outcomes for skilled migrants which has been drawn from the three waves of interviews for New Zealand's first longitudinal survey of immigrants. This survey was initiated soon after the EOI system had become operational and migrant labour market outcomes can be 
compared with data relating to skilled migrants interviewed in a similar survey in Australia at the same time but without an EOI stage in the selection process. In the conclusion, the decision by Australia's Department of Citizenship and Immigration to adopt a variant of the EOI model from July 2012 is revisited as is Citizenship Immigration Canada’s decision to introduce their variant of the model from January 2015.

\section{Selecting migrants "by invitation”: implementation of the EOI system, 2003-2005}

In July 2003, Lianne Dalziel, New Zealand's Minister of Immgration at the time, announced a package of policy changes that shifted the migrant selection system from what was effectively a passive acceptance of residence applications that met particular points thresholds to a much more targetted and active selection of prospective residents with skills which were in demand in the labour market (Department of Labour, 2008). Dalziel (2003: 1) described the new selection system in the following words:

Instead of lodging applications for residence, potential migrants will, in future, register an expression of interest, based on the existing pre-requisites of health, character and English language. In order to register, a minimum number of points will be required. The current points system will be expanded to include bonus points, for example, by meeting a specific skill shortage or having a skilled job offer in a region outside Auckland. This does not mean Auckland misses out either. It means that Auckland's needs drive skilled migration to Auckland.

Those who register their interest will be pooled, and those achieving the highest level of points will be invited to apply for residence. Where no invitation to apply has been issued by the end of the registration period, the registration will lapse. This will probably occur quarterly.

Once an application for residence is lodged, two streams will emerge. The first stream will consist of those who have already demonstrated that they can settle and do well here. For example, they may have successfully studied or worked in New Zealand, or they have a skilled job offer, which demonstrates that a New Zealand employer has made that assessment. People in this stream will flow through to residence. 
The second stream will consist of those who have not yet demonstrated their ability to settle in New Zealand, as in the first stream. The majority of these will be managed through a two year work-to-residence programme, rather than gaining residence outright. This will enable them to demonstrate their ability to settle and gain relevant employment. This essentially means that they carry the risk of not achieving this outcome rather than the New Zealand welfare system that has had to meet the cost of failure until now. ...

... The most significant aspect of these changes is that those potential migrants, who best meet New Zealand's needs, will be at the top of the list for the invitation to apply, and those with the demonstrated ability to settle here, particularly those with a skilled, relevant job offer, will have a fast track to residence.

A new skilled migrant category (SMC) was introduced on 17 December 2003 after a six month transition period to clear the backlog of applications under the former General Skills category which was closed in July 2003. The points categories and their respective allocations in December 2003, which were used in the first draw from the pool of EOIs, are listed in Table 1. It is clear from the numerous categories relating to employment (job offer and location of employment, previous work experience and location of this experience) that selection into the SMC was very much influenced by factors linked with paid work. The bias in favour of tertiary-trained graduates, that had characterised the points system introduced in 1991, had been effectively removed - applicants with trades qualifications that were recognised in New Zealand got almost as many points (50) as those with postgraduate qualifications (55). Family support made no contribution to the overall total in the initial allocation of points (Table 1).

[Table 1: Points categories and allocations, Skilled Migrant category, 2003-2005] 
A high selection threshold of 195 points was set initially but this did not deter applicants. There were almost 2,000 EOIs in the pool at the time of the first draw on 18 February 2004 and 126 of these, covering 371 people, were selected to receive an invitation to apply for residence. All of the applicants selected either already had jobs in New Zealand, or had a job offer. By far the highest share were citizens of the United Kingdom (42 percent), with South Africa (12 percent) having the second largest proportion. India (8 percent) and the United States of America (6 percent) were the only other countries with more than 3 percent of the total approvals. At this early stage, China did not feature in the top 10 source countries of applicants selected in the draw from the pool - the Chinese citizens who did put in EOIs could not meet the initial high points threshold for selection.

The selection point dropped to 185 for the fortnightly draws from the pool in March 2004, to 180 for the first two draws in April, then to 160 by the end of May, 150 at the end of June and 130 by the end of July. In all of these draws, 100 percent of those selected from the pool either had jobs in New Zealand or had a firm offer of employment. In August, the points required were reduced to 115 and then 110 before stabilising at 100 from 1 September until the end of December 2005. The proportions either in employment or with job offers fell sharply once the points dropped below 115 and from late August 2004 until December 2005, the proportions of applicants with no job offer who were selected from the pool ranged between 40 and 60 percent. Most of these applicants would have been be required to follow the route to residence that involved two years in transition via work in New Zealand.

Over the period between 18 February 2004 and 21 December 2005 (the last draw from the pool when the selection point was 100), a total of 36,840 EOIs were selected covering 88,518 people. Citizens of the United Kingdom remained the major group of applicants with points 
at or above the selection point through to December 2005. The UK share remained above 40 percent until 26 May 2004 when the number of points required for selection dropped to 160. From May 2004 until 23 November 2005, the United Kingdom remained the first ranked source country accounting for between 24 and 38 percent of all applicants at or above the selection point in each fortnightly draw. The second ranked source country fluctuated between South Africa, India, China and the Philippines. In the two draws during December 2005, China had the highest shares of applications at or above the recommended selection point of 100, with the United Kingdom a close second. This was the first time another country had surpassed the United Kingdom as the major source of applicants selected in the fortnightly draws from the pool.

In December 2004, a number of changes were made to the points allocation in the SMC (Table 1). These related especially to the points for skills, qualifications and employment in areas of absolute skill shortage in New Zealand. The amended points are highlighted in Table 1 (bold, italics). An allocation of points in recognition of support provided by close family already living in New Zealand was also made - the first time 'family in New Zealand' was allowed to count for something in the new selection system. A greater range of trade qualifications was also recognised under the SMC - testimony to the intensifying demand for labour with a wide range of skills in the New Zealand economy.

The percentages of the 10,054 principal applicants applying under the SMC between July 2004 and June 2005, who qualified for points in the different categories, are listed in the final column of Table 1. Just under three-quarters (74 percent) gained points for being aged between 20 and 39 years, and 70 percent qualified for points because they had skilled employment in New Zealand at the time of application, with just over 30 percent having had 
such work for 12 months or more. In terms of qualifications, 71 percent gained points for having recognised trades or undergraduate tertiary qualifications, with only 12 percent gaining points for postgraduate qualifications. Just under 30 percent gained points for having a recognized qualification in an area of absolute skill shortage. Over 60 percent of those who specified a location for their employment or offer of a job qualified for points if the location was outside the Auckland region, with 25 percent getting additional points for jobs in areas of absolute skill shortage (Table 1).

Following the national elections in November 2005 and the return of the Labour Government that had introduced the two-stage selection process, the Minister of Immigration (David Cunliffe) sought a review of the SMC. It was becoming apparent that the SMC selection mechanism, operating on a points threshold of 100, was resulting in demand for residence approvals in excess of the annual approved total of $23,700(+3,000)$ skilled migrant principal applicants and their spouses/partners and dependent children ${ }^{3}$. By holding the selection threshold at 100 points for over 12 months, despite increases in the numbers of applicants reaching this level or higher, there had been a build up of EOIs selected which could not be assessed because their numbers exceeded the places available in the SMC. By December 2005, the excess demand for residence by applicants with 100 points or more was estimated to be around 9,500.

\section{Two stages and two tiers: the EOI system in operation, 2006-2008}

On 15 December 2005, Cabinet approved the introduction of a two-tier selection mechanism for the SMC in order to limit future over-subscription (Cabinet Business Committee, 2005). The new SMC selection mechanism pooled EOIs meeting the 100 point minimum for up to

\footnotetext{
3 The total of 23,700 for the SMC does not include the 3,300 places allocated for the various business and entrepreneur categories, giving the total of 27,000 places in the skilled and business categories
} 
six months with fortnightly selections at which EOIs scoring 140 points or above were automatically selected while those scoring between 100 and 135 points with a skilled job or a job offer were ranked by their total points and selected in sufficient numbers to meet the requirements of the New Zealand Immigration Programme (NZIP) according to their points ranking. Other EOIs with the required points but no job offer could be selected, but only if places were available. Cabinet also approved a reduction in the time an applicant, who was granted a work permit to allow them to transition to residence, would have to find appropriate work. The two year transition period was reduced to six months in the belief that, given the high demand for skilled labour, this would encourage those with provisional approval for residence to move more rapidly to full residence status.

Six broad categories are used in the selection of migrants under the two-tier system:

1) EOIs with 140 points or above with or without a job offer (automatically selected).

2) EOIs with a points total of 100 or more but less than 140, including points for offers of skilled employment or current skilled employment in New Zealand.

3) EOIs with a points total of 100 or more but less than 140, including 15 points for work experience in an area of absolute skill shortage.

4) EOIs with a points total of 100 or more but less than 140, including 10 points for work experience in an area of absolute skill shortage.

5) EOIs with a points total of 100 or more but less than 140, including 10 points for a qualification in an area of absolute skill shortage.

6) EOIs that had a points total of 115 or more but less than 140 without points for offers of employment or current skilled employment, work experience in an area of absolute skill shortage or for a qualification in an area of absolute skill shortage. These EOIs were ranked in descending order of points. 
In February and March 2006, only the first three categories were used to fill the fortnightly selections. Around a third of those selected during February were from the UK with only 17 percent from China - a very different mix from those at or above the selection point of 100 on 21 December 2005 when 31 percent were citizens of China and 26 percent UK citizens. In most fortnights from March to November, there were EOIs in the $4^{\text {th }}$ category in the list, and for 12 of the 24 draws (between June and early October), there were selections of category 5 EOIs. In only 5 weeks in 2006 were there selections of EOIs that did not have any points for offers of skilled work, or work experience or qualifications in an area of absolute skill shortage. The numbers selected in this latter category for invitations to apply for residence comprised only 2.8 percent of the 16,067 EOIs selected during the year (Table 2).

[Table 2: Selection of EOIs by points category, 2006-2008]

During 2007 and 2008, the fortnightly selections were larger than those in 2006 as a result of a decision by the Minister of Immigration and the Cabinet to increase the limits for the three major streams in the New Zealand Residence Programme (NZRP) from December 2006. The average numbers of EOIs selected each fortnight in 2007 and 2008 were 766 and 774 respectively, compared with 690 in 2006. The distribution of EOIs selected across the six categories was very similar in 2007 to that in 2006, with 77 percent in both years in the first two categories (Table 2). In 2008, the share in the first two categories fell to 73 percent with a larger share in the category with points between 110 and 135 but no points for work experience or qualifications in areas of absolute skill shortage. The limits approved for the skilled and business stream in the 2005/06 and 2006/07 years were 27,000 (+5,000), and 28,200-31,000 respectively, and these are reflected in the larger average selections from the pool each fortnight in the calendar years 2007 and 2008 (Table 2). 
The top five countries in terms of numbers of EOIs submitted by their citizens that were selected in these three years were: United Kingdom, China, South Africa, India and the Philippines (Table 3). UK citizens had the highest proportion of EOIs in 2006 and 2008 with China having a slightly higher share than the UK in 2007. South Africans, Indians and citzens of the Philippines increased their shares of EOIs in successive years but, of these three, only South Africa had a first ranking in a fortnightly selection (in 2008). In 2006, UK citizens accounted for the highest share of EOIs selected in 22 of the 24 fortnightly draws from the pool. Citizens of China were first ranked in the other two selections in that year (Table 3). The situation was very different in 2007, however - EOIs for citizens of China were the most numerous in 13 of the fortnightly selections, with UK citizens dominating in the other 12. In 2008, UK citizens reasserted their lead in 15 of the selections, with Chinese leading in 9 and South Africans in the remaining one.

[Table 3: EOIs selected by nationality, location and job offer, January 2006-December 2013]

EOIs selected from these five countries accounted for 68-69 percent of the totals selected, and over two-thirds of the applications had been made on-shore in New Zealand. The great majority of applicants had a job or a job offer at the time they submitted their EOI - 72 percent in 2006 and 2007 and 65 percent in 2008 (Table 3). The increase in numbers without a job offer in 2008 was clearly associated with the increasing number of selections when EOIs were drawn from all six of the points categories - in 20 of the 25 selections in that year the six categories were used, whereas in 2006 and 2007, only 5 and 6 selections respectively used all six categories, and especially the category which included applicants with no points 
for a job offer, work experience or education qualifications in an area of absolute skill shortage in New Zealand.

Over the three years, few changes were made to the points allocation for the skilled migrant system or to the points required for selection from the pool. The points allocated to the different categories in the years which ended in June 2006 and 2007 were the same as those listed for December 2004 in Table 1. Some minor changes were made for the 2007/08 financial year to increase the points allocated for offers of employment in defined areas of growth, for length of work experience in New Zealand and for any qualifications gained in New Zealand. Additions were also made to the long-term and the immediate skill shortage lists between 2006 and 2008 which increased opportunities for migrants with appropriate skills to qualify for the bonus points available for relevant work experience. The two Ministers of Immigration (Cunliffe and Cosgrove) between January 2006 and November 2008 maintained a consistent policy of encouraging migrants with skills who were interested in taking up residence in New Zealand. As a result, the numbers of people approved for entry in the EOIs that were selected increased each year from 36,293 in 2006 to 42,347 in 2007 and 45,414 in 2008. The total people approved in the three years was just over 124,000 with around 84,000 coming from the five key source countries listed in Table 3.

The gradual recognition, from October 2008, that a global financial crisis was going to have a serious impact on economic growth and employment levels did not generate immediate pressure for a change in immigration policy. A new Minister of Immigration (Dr Jonathan Coleman) in the National Government confirmed, in February 2009, that the selection categories would remain in force and indicated that he would maintain the average number of EOIs selected each fortnight during 2008 through until July 2009. 


\section{Coping with crises: policy responses to GFC and the Christchurch earthquakes}

During the first six months under the National Government, there was not much change in the numbers and characteristics of the EOIs selected. The main changes were the on-going shift in shares of applications selected from citizens of India, the Philippines and 'other countries' at the expense of those from citizens of the UK, China and South Africa. The situation changed after July 2009, however. The Minister of Immigration removed several occupations from the long-term skill shortage list in that month and, while the overall target for new migrant approvals in the residence programme for the year ended June 2010 remained within the range 45,000-50,000 (25,000-27,300 in the SMC), despite the GFC and rising unemployment in New Zealand, the number of EOI selected every two weeks was reduced and the fortnightly average fell from 770 to 654 . The GFC was having an impact on the volume as well as the compostion of the applicants selected from the pool.

There was a further decline in the proportion of selected EOIs from citizens of the United Kingdom, China and South Africa. The only country in the top five to increase its share was India (Table 3). In the draw for 16 December 2009, India was the top-ranked source country for the first time. Over the subsequent three years, the EOIs submitted by citizens of India became increasingly dominant and by 2013, they accounted for between 24 and 33 percent of every fortnighly selection from the pool. This compared with 9-13 percent for UK citizens, 8-13 percent for citizens of China and 8-12 percent for citizens from the Philippines. During this period, the other source country regularly in the top five, South Africa, dropped back to between 2 and 5 percent of selections in each draw in 2013.

Table 3 gives an indication of the general trends in both the numbers of EOIs selected from the pool and the nationalities of those submitting EOIs over the eight years since the two-tier 
system with its six categories was introduced. For the first four years, the numbers of EOIs (and the people linked with these) increased but during the following four years, these dropped back, mainly due to a combination of the impact of the GFC on some major source countries (especially the UK) and rising domestic unemployment in New Zealand. Between January 2006 and December 2009, 75 percent of all the EOIs selected indicated that the applicant either had 140 or more points or was either already in employment in New Zealand, or had a verifiable job offer. Over the subsequent four years, the share in the first two of the six categories increased to 90 percent.

Between 2009 and 2013, the shares of EOIs selected for citizens of India more than doubled from 12.2 percent in 2009 to 28.8 percent in 2013, effectively reversing the situation involving EOIs for UK citizens which declined from 27.4 percent in 2006 to 11 percent in 2013 (Table 3). The same five countries remained the main sources of EOIs through the period but their relative significance in the pool changed quite markedly over time. This was not due to policy changes or to specific changes in selection criteria that favoured traditional sources of migrants, such as the UK (Spoonley and Bedford, 2012). Rather it was the result of differences in response to residence opportunities by migrants in the major course countries, with those from China having a comparative disadvantage in coming from a country where English was spoken much less widely than in the other four major sources. By 2013, more EOIs submitted by citizens from India were being selected from the pool every fortnight - they had assumed the place in the league table for selections that the UK had held through much of the period since the EOI model had been adopted (Table 3).

During its two terms of office since the 2008 elections, the National Government has focussed attention on ensuring that migrants, who had been selected under the SMC, 
achieved good labour market outcomes from the time they were approved for residence - an approach reinforced by findings from New Zealand's longitudinal immigration survey (LisNZ) and the comparative analysis of labour market outcomes for migrants in New Zealand and Australia completed by Hawthorne in 2011 (see below). The best way to achieve this was just to select migrants with jobs or job offers in New Zealand (Table 4). By 2013, the great majority of those who did not have jobs or job offers were actually in the $140+$ points category who were automatically entitled to receive an invitation to apply for residence. During 2013 1,668 (14 percent) of the 11, 834 EOIs selected with 140+ points did not specify having a job or a job offer in the application. These high-scoring EOIs accounted for two-thirds of the total EOIs selected $(2,519)$ with no job offer in 2013.

[Table 4: Selection of EOIs by points category 2009, 2011 and 2013]

Disentangling the impacts of the GFC and two devastating earthquakes in Christchurch in September 2010 and February 2011 on the selection of skilled migrants is difficult using readily available data on the migrant selection process. Accompanying the GFC was a decline in applications for residence in New Zealand, partly associated with the impacts of the financial crisis on source countries, and partly associated with a rise in unemployment in New Zealand which prompted a cautious approach to the selection of EOIs where there was no evidence of a job or job offer (Table 4). The earthquakes in Christchurch certainly discouraged migration to New Zealand's second largest city. But the decision in December 2013 to proceed with rebuilding the cit has generated a high demand for skilled labour to assist with this (Ministry of Business, Innovation and Employment, 2013a). However, much of the migration associated with the rebuilding is, and will continue to be, temporary rather than through applications for residence under the SMC. Temporary work visas - much more 
than residence visas - help fill skill shortages in New Zealand, in common with Australia, Canada and many other parts of the world (Ministry of Business, Innovation and Employment, 2013b).

\section{Labour market outcomes for migrants: a comparative analysis}

In 2011, the New Zealand Department of Labour and the Australian Department of Citizenship and Immigration commissioned a comparative study of the labour market outcomes of skilled migrants using data from longitudinal immigration surveys conducted in both countries between 2005 and 2008. Hawthorne (2011) carried out this analysis which has had a significant impact on immigration policy in both countries. In a brief summary of her main study ${ }^{4}$, she observed that at the time of the two longitudinal surveys (LISIA 3, Australia and the LisNZ, New Zealand) key similarities and differences in skilled migrant selection criteria included:

1) significant English language requirements in both countries, with New Zealand having the more stringent requirements at the time (2005);

2) relevant work experience (especially local experience) more highly valued within the New Zealand points system;

3) occupational demand a key determinant of selection for both countries;

4) Australian age requirements more rigid that New Zealand's, with people aged over 45 being ineligible for the skilled migrant category compared with 55 years in New Zealand.

\footnotetext{
${ }^{4}$ The key findings from Hawthorne's (2011) report are summed up in a short "At a Glance" publication entitled "Competing for skills: migration policies and trends in New Zealand and Australia" which is available (along with the full report, and an extensive Executive Summary) at http://www.dol.govt.nz/publications/research/competing-for-skills/report/.
} 
The key finding from the study with regard to labour market outcomes for skilled migrants who had been interviewed at 6 months, 18 months and three years after arrival were:

A comparative analysis of longitudinal survey data highlighted that skilled migrants in New Zealand were more likely to be working, and if working, were more likely to be earning more than in Australia. New Zealand's choice of relatively mature skilled migrants seems to have been immediately beneficial in terms of labour market integration, although there is evidence of this gap narrowing over time. New Zealand migrants' greater work experience and greater English language proficiency are likely to have compensated for lower qualification levels. The two-step migration paradigm adopted by New Zealand and Australia appears highly effective, regardless of whether the work to residence pathway [New Zealand] or the study-migration pathway [Australia] is used.

Since the mid-2000s, both countries have refined their selection policies for skilled migrants. New Zealand has continued to use a centrally-managed points selection system as the main vehicle for managing both employer demand as well as responding to migrant supply, and the EOI model has become an integral part of the selection system. The skilled migrants who were interviewed in the LisNZ had all been approved for entry to New Zealand under the early EOI model - the pre-2006 two-tier selection system. The positive labour market outcomes for these migrants that Hawthorne (2011) reports are obviously due mainly to the human capital that the migrants bring to jobs which they had negotiated before seeking residence in New Zealand. But a part of their success is also due to the EOI model that allowed for the much more active selection of migrants by the Department of Labour through a pool of applicants who themselves were very conscious of the key requirements for selection of their EOIs and a subsequent invitation to apply for residence.

\section{Conclusion}

By December 2013, a decade after the EOI model was introduced in New Zealand, a total of 166,247 EOIs, representing 317,034 people, had been selected from the pool of applicants. 
On 12 December 2013, after the last selection for the year was completed, there were 988 EOIs in the pool - a very different situation from a decade earlier when there was a backlog of several thousands of applications awaiting processing under the General Skills Category of the day. The EOI model, with its two-tier stucture that guarantees an invitation for people who meet a specified points total (subject to verification of evidence that various selection criteria have been met), and allows for flexibility in terms of the numbers selected from categories below this first tier, coupled with its maximum period of six months for an application to remain in the pool, has eliminated the backlog. In terms of delivering on a key policy requirement for the SMC, namely timely entry into employment by principal applicants along with positive labour market outcomes, the Hawthorne (2011) report and ongoing research sponsored by Immigration New Zealand ${ }^{5}$ (e.g. Stillman, 2011, Immigration New Zealand, 2013) provide evidence that the selection system is delivering on its primary objectives.

As noted in the introduction to this paper, New Zealand's success with this process for selecting potential skilled migrants has been noticed by two of its main competitors for 'global talent'. The Australian Department of Citizenship and Immigration developed its own variant of the EOI model, SkillSelect, for managing the supply-driven component of their skilled migration. Australia has a much more targetted demand-driven component to skilled migration than New Zealand, with employers and States having the ability to nominate around two-thirds of the skilled migrants who enter the country each year (Cully, 2011). In his review of skilled migrant selection policies, Cully $(2011,7)$ concluded that there was qualified support from survey evidence for the new selection system that Australia

\footnotetext{
${ }^{5}$ The Department of Labour, which includes the New Zealand Immigration Service (Immigration New Zealand), was merged with a number of other government agencies to form the Ministry of Business, Innovation and Employment in 2012.
} 
introduced in 2012, which includes an EOI stage, and a specified points threshold for automatic selection from the pool (Department of Immigration and Citizenship, 2013). He went on to observe that his analysis had shown "that for a country like Australia [and Canada and New Zealand], which is blessed in having more people wishing to migrate to it than places it makes available, migrant selection policies do work: they deliver markedly superior labour market outcomes than would accrue if would-be migrants were chosen at random.”

Maia Welbourne (Senior Director of Strategic Policy and Planning in Citizenship Immigration Canada) agrees. In her statement to the Standing Senate Committee on Foreign Affairs and International Trade on 20 November 2013 she reviewed the advantages of the EOI model as a component of a faster and more flexible immigration system and noted:

Primarily, the introduction of EOI is designed to improve application management. By only issuing invitations to apply to the number of applicants that we can process, we will prevent the inventories that have accumulated in the past and associated legal risk. The new system will facilitate the arrival of the candidate best suited to Canada's needs rather than the first person who applied. ...

A second feature of this system is its ability to increase the immigration system's labour market responsiveness. ... The Expression of Interest system seeks to combine the strengths of the human capital model with the benefits of having immigrants arriving in Canada with employment, ready to work.

The EOI approach also represents an opportunity to strengthen the role of provinces and territories in immigrant selection. ... The ability of provinces and territories to access EOI candidates through an EOI portal will allow EOI candidates to be invited to apply to a provincial nominee program. ${ }^{6}$

\footnotetext{
${ }^{6}$ The Standing Committee on Foreign Affairs and International Trade. Evidence. Ottawa, Wednesday 20 November 2013. http://www.parl.gc.ca/content/sen/committee/412/AEFA/51031-E.htm (accessed 23 January 2014).
} 
New Zealand's innovative approach to eliminating an applicant backlog of residence applications from skilled migrants and improving labour market outcomes for skilled migrants who are approved for residence has been given the strong endorsement. The two countries it competes most directly with for 'global talent' have decided to adopt the same model for the supply-driven elements of their skilled migration programmes.

\section{$\underline{\text { References cited }}$}

Alboim, N. and Cohl, K. 2012. Shaping the Future: Canada's Rapidly Changing Immigration Policy. Toronto, Maytree.

http://maytree.com/spotlight/shaping-the-future-canadas-rapidly-changing-immigrationpolicies.html (accessed 18 February 2014)

Bedford, R. 2004. "The quiet revolution: transformations in migration policies, flows and outcomes, 1999-2004”, New Zealand Geographer 60(2): 58-62.

Bedford, R. 2006. "Skilled migration in and out of New Zealand: immigrants, workers, students and emigrants.” In R. Birrell, L. Hawthorne and S. Richardson, Evaluation of General Skilled Migration Categories (pp. 224-251). Canberra: Commonwealth of Australia.

Bedford, R., Ho, E. and Lidgard, J. 2005. "From targets to outcomes: immigration policy in New Zealand, 1996-2003.” In A. Triln, P. Spoonley and N. Watts (eds) New Zealand and International Migration: A Digest and Bibliography No. 4 (pp.1-43). Palmerston North: Department of Sociology, Social Policy and Social Work, Massey University.

Bedford, R., Callister, P. and Didham, R. 2010. “Arrivals, departures and net migration, 2001/02-2008/09.” In In A. Triln, P. Spoonley and R. Bedford (eds) New Zealand and International Migration: A Digest and Bibliography No. 5 (pp. 50-101). Palmerston North: Department of Sociology, Social Policy and Social Work, Massey University. 
Birrell, R., Hawthorne, L. and Richardson, S., 2006. Evaluation of General Skilled Migration Categories. Canberra: Commonwealth of Australia (with extended appended essays on Canada, New Zealand and the United Kingdom)

http://www.immi.gov.au/media/publications/research/gsm-report/index.htm (accessed 20 February 2014).

Cabinet Business Committee 2005. Skilled migrant selection and excess demand for residence. CBC (05) 390, 15 December 2005, New Zealand Government, Wellington.

Cobb-Clark, D. 2000. "Do selection criteria make a difference? Visa category and the labour market status of immigrants in Australia”, Economic Record 76: 15-31.

Cully, M., 2012. “Skilled migration selection policies: recent Australian reforms”, Migration Policy Practice 1(1): 4-7.

Cully, M. Lim, K., Smith, D. and Levantis, C. 2011. Do Skilled Selection Policies Work? A Case Study of Australia. Canberra: Department of Immigration and Citizenship Staff Research Paper No. 3.

Dalziel, L. 2003. Skilled immigration policy announcements. Media statements and briefing notes, 1 July 2003, Office of the Minister of Immigration, Parliament Buildings, Wellington.

Department of Labour 2004. Migration Trends 2003/04. Wellington: Workforce Group, Department of Labour.

Department of Labour 2005. Migration Trends 2004/05. Wellington: Workforce Group, Department of Labour.

Department of Labour 2008. Migration Trends 2006/07. Wellington: IMSED Research, Department of Labour.

Department of Immigration and Citizenship 2013. Annual Report 2012-13. Canberra: Commonwealth of Australia. 
http://www.immi.gov.au/about/reports/annual/2012-13/pdf/2012-13-diac-annual-report.pdf (accessed 29 January 2014)

Hawthorne, L. 2005. "Picking winners: the recent transformation of Australia's skill migration policy”, International Migration Review 40(6): 55-92.

Hawthorne, L. 2007. Labour Market Outcomes for Migrant Professionals: Canada and Australia Compared. Ottawa: Citizenship Immigration Canada. www.cic.gc.ca/english/resources/research/2006-canada-australia.asp (accessed 20 February 2014)

Hawthorne, L. 2008. The Impact of Economic Selection Policy on Labour Market Outcomes for Degree-Qualified Migrants in Canada and Australia. Ottawa: Institute for Research on Public Policy.

Hawthorne, L. 2011. Competing for Skills: Migration Policies and Trends in New Zealand and Australia. Wellington: Department of Labour, IMSED Research.

http://www.dol.govt.nz/publications/research/competing-for-skills/report/ $\quad$ (accessed 20 February 2014).

Hiebert, D. 2006. “Skilled migration in Canada: context, patterns and outcomes." In R. Birrell, L. Hawthorne and S. Richardson, Evaluation of General Skilled Migration Categories (pp. 182-223). Canberra: Commonwealth of Australia.

Immigration New Zealand (2013) Employers' Role and Influence in Migration: A Literature Review. Wellington: Ministry of Business, Innovation and Employment. http://www.dol.govt.nz/publications/research/employers-role-influence-migration-lit-review/

Jasso, G. and Rosenzweig, M. 2009. "Selection criteria and the skill composition of migrants: a comparative analysis of Australian and US employment immigration.” In J. Bhagwati and G. Hanson (eds) Skilled Immigration Today: Prospects, Problems and Policies (pp. 153-182). New York: Oxford University Press. 
Ministry of Business, Innovation and Employment 2013a. Migration Trends Key Indicators Report, June 2013. Wellington: Labour and Immigration Research Centre, Ministry of Business, Innovation and Employment.

Ministry of Business, Innovation and Employment 2013b. Migration Trends and Outlook 2011/2012. Wellington: Labour and Immigration Research Centre, Ministry of Business, Innovation and Employment.

Papadametrious, D. and Sumpton, M. 2013. Attracting and Selecting from the Global Talent Pool - Policy Challenges. Washington: Migration Policy Institute Report.

Spoonley, P. and Bedford, R. 2012. Welcome to our World? Immigration and the Reshaping of New Zealand. Auckland: Dunmore Press.

Stillman, S. (2011) Labour Market Outcomes for Immigrants and the new Zealand-Born 1997-2009, Wellington: IMSED Research, Department of Labour.

http://www.dol.govt.nz/publications/research/labour-market-outcomes/Index.asp 
Table 1: Points categories and allocations, SMC 2004-05

\begin{tabular}{|c|c|c|c|}
\hline \multirow[b]{2}{*}{ Category } & \multicolumn{2}{|c|}{$\begin{array}{l}\text { Points allocated } \\
\text { December }\end{array}$} & \multirow{2}{*}{$\begin{array}{c}\% \text { receiving } \\
\text { points } \\
2004 / 05\end{array}$} \\
\hline & 2003 & 2004 & \\
\hline \multicolumn{4}{|l|}{ Skilled employment } \\
\hline Skilled employment 12 months or more & 60 & 60 & 31 \\
\hline Skilled employment under 12 months & 50 & 50 & 37 \\
\hline Offer of skilled employment & 50 & 50 & 19 \\
\hline No employment & 0 & 0 & 13 \\
\hline \multicolumn{4}{|l|}{ Bonus points for employment/offer of employment } \\
\hline Identified future growth area & 5 & 5 & 11 \\
\hline Identified cluster area & 5 & 5 & 1 \\
\hline In an area of absolute skill shortage & 5 & 10 & 25 \\
\hline In a region outside Auckland & 10 & 10 & 62 \\
\hline Partner employment or offer of employment & 10 & 10 & 6 \\
\hline \multicolumn{4}{|l|}{ Relevant work experience } \\
\hline 2 years & 10 & 10 & 13 \\
\hline 4 years & 15 & 15 & 12 \\
\hline 6 years & 20 & 20 & 11 \\
\hline 8 years & 25 & 25 & 9 \\
\hline 10 years & 30 & 30 & 35 \\
\hline \multicolumn{4}{|l|}{ Bonus points for New Zealand work experience } \\
\hline 2 years & 5 & 5 & 10 \\
\hline 4 years & 10 & 10 & 2 \\
\hline 6 years & 15 & 15 & 0 \\
\hline \multicolumn{4}{|l|}{ Additional bonus points for work experience } \\
\hline Identified future growth area or cluster (2-5 years) & 5 & 5 & 3 \\
\hline Identified growth area or cluster ( 6 years or more) & 10 & 10 & 4 \\
\hline Area of absolute skills shortage (2-5 years) & 5 & 10 & 8 \\
\hline Area of absolute skills shortage (6 years or more) & 10 & 15 & 17 \\
\hline \multicolumn{4}{|l|}{ Qualifications (all must be recognised in NZ) } \\
\hline Basic qualification (trades and tertiary undergrad) & 50 & 50 & 71 \\
\hline Postgraduate qualification (Masters/PhD) & 55 & 55 & 12 \\
\hline \multicolumn{4}{|l|}{ Bonus points for recognized qualifications } \\
\hline NZ qualification (and at least 2 years study in NZ) & 10 & 10 & 10 \\
\hline Qualification in an identified future growth area & 5 & 5 & 7 \\
\hline
\end{tabular}


Qualification in an identified cluster area

Qualification in an area of absolute skills shortage

Partner qualifications

Close family support in New Zealand

Age (20-55 years)

20-29

30-39

40-44

45-49

50-55

Source: Department of Labour $(2004,2005)$

Table 2: Selection of EOls by points category, 2006-2008

\begin{tabular}{|c|c|c|c|}
\hline \multirow[b]{2}{*}{ Points category } & \multicolumn{3}{|c|}{ Calendar Year } \\
\hline & 2006 & 2007 & 2008 \\
\hline \multicolumn{4}{|l|}{ Numbers } \\
\hline $140+$ points & 9,909 & 12,127 & 11,621 \\
\hline $100-135$ pts + job offer & 2,460 & 2,822 & 2,655 \\
\hline $100-135$ pts +15 pts work experience & 1,871 & 1,665 & 1,326 \\
\hline $100-135$ pts +10 pts work experience & 701 & 865 & 820 \\
\hline $100-135$ pts +10 pts qualifications & 675 & 1,087 & 1,380 \\
\hline $110-135$ pts no pts work/qualifications & 451 & 578 & 1,555 \\
\hline Total & 16,067 & 19,144 & 19,357 \\
\hline Average per fortnightly selection & 669 & 766 & 774 \\
\hline \multicolumn{4}{|l|}{ Percentages } \\
\hline $140+$ points & 61.7 & 63.3 & 60.0 \\
\hline $100-135$ pts + job offer & 15.3 & 14.7 & 13.7 \\
\hline $100-135$ pts +15 pts work experience & 11.6 & 8.7 & 6.9 \\
\hline $100-135$ pts +10 pts work experience & 4.4 & 4.5 & 4.2 \\
\hline $100-135$ pts +10 pts qualifications & 4.2 & 5.7 & 7.1 \\
\hline $110-135$ pts no pts work/qualifications & 2.8 & 3.1 & 8.1 \\
\hline Total & 100.0 & 100.0 & 100.0 \\
\hline
\end{tabular}

Source: Fortnightly Selection Statistics, Department of Labour website www.immigration.govt.nz/migrant/stream/work/skilledmigrant/ 
Table 3: EOIs selected by nationality, location and job offer January 2006 - December 2013

\begin{tabular}{|c|c|c|c|c|c|}
\hline \multirow[b]{2}{*}{ Characteristic } & \multicolumn{5}{|c|}{ Calendar Year } \\
\hline & 2006 & 2007 & 2008 & 2009 & 2013 \\
\hline \multicolumn{6}{|l|}{ Numbers } \\
\hline EOI selected & 16,067 & 19,144 & 19,357 & 17,740 & 14,999 \\
\hline People selected & 36,292 & 42,374 & 45,414 & 40,121 & 29,312 \\
\hline Av. EOI/fortnightly selection & 670 & 766 & 774 & 710 & 600 \\
\hline \multicolumn{6}{|l|}{ EOls by nationality (\%) } \\
\hline United Kingdom & 27.4 & 21.5 & 19.3 & 16.9 & 11.0 \\
\hline China (PRC) & 18.0 & 23.1 & 17.5 & 14.3 & 11.2 \\
\hline South Africa & 7.3 & 8.3 & 12.3 & 9.9 & 4.1 \\
\hline India & 8.3 & 8.3 & 9.2 & 12.2 & 28.8 \\
\hline Philippines & 7.9 & 8.3 & 10.7 & 10.7 & 9.4 \\
\hline Sub-total & 68.9 & 69.5 & 68.4 & 64.0 & 64.5 \\
\hline Other countries & 31.1 & 30.5 & 31.6 & 36.0 & 35.5 \\
\hline Total & 100.0 & 100.0 & 100.0 & 100.0 & 100.0 \\
\hline \multicolumn{6}{|l|}{ Selections when first ranked } \\
\hline United Kingdom & 22 & 12 & 15 & 22 & 0 \\
\hline China & 2 & 13 & 9 & 2 & 0 \\
\hline South Africa & 0 & 0 & 1 & 0 & 0 \\
\hline India & 0 & 0 & 0 & 1 & 25 \\
\hline Philippines & 0 & 0 & 0 & 0 & 0 \\
\hline Total & 24 & 25 & 25 & 25 & 25 \\
\hline EOIs processed on-shore (\%) & 65.5 & 69.4 & 66.4 & 60.4 & 76.5 \\
\hline EOIs with job or job offer (\%) & 72.1 & 72.2 & 65.3 & 65.9 & 83.2 \\
\hline
\end{tabular}

Table 4 next page 
Table 4: EOI selection by points category 2009, 2011, 2013

\begin{tabular}{l|rrr} 
& \multicolumn{3}{|c}{ Calendar Year } \\
Points category & $\mathbf{2 0 0 9}$ & $\mathbf{2 0 1 1}$ & $\mathbf{2 0 1 3}$ \\
\hline & & & \\
Numbers & 10,225 & 9,884 & 11,834 \\
$140+$ points & 2,726 & 2,339 & 2,934 \\
$100-140$ pts + job offer & 4,789 & 2,008 & 231 \\
No job offer categories & & & \\
& 17,740 & 14,231 & 14,999 \\
Total & 710 & 569 & 600 \\
Average per fortnightly selection & & & \\
& & & \\
& & & \\
Percentages & 57.6 & 69.5 & 78.9 \\
$140+$ points & 15.4 & 16.4 & 19.6 \\
$100-135$ pts + job offer & 27.0 & 14.1 & 1.5 \\
No job offer categories & & & \\
Total & 100.0 & 100.0 & 100.0 \\
\hline
\end{tabular}

Source: Fortnightly Selection Statistics, Department of Labour website www.immigration.govt.nz/migrant/stream/work/skilledmigrant/ 